\title{
Petrographic and Chemical Research on Furnace Wastes From Individual Heating Furnaces and Boilers - Method for Identification of Co-Burning Municipal Waste
}

\author{
Wojciech Szulik \\ Centralne Laboratorium Pomiarowo-Badawcze Sp. z o. o., Poland \\ Iwona Jelonek \\ University of Silesia, Poland
}

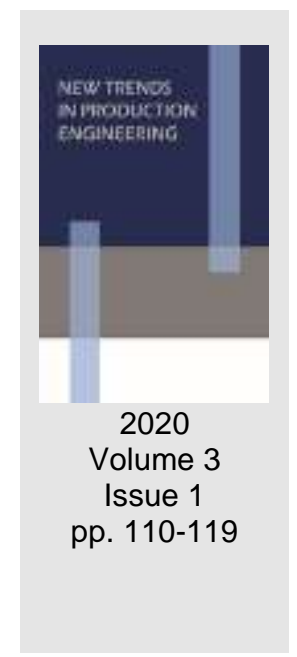

Date of submission to the Editor: 02/2020

Date of acceptance by the Editor: 03/2020

\section{INTRODUCTION}

In the area of solid energy carriers used for economic purposes, there is a phenomenon of doping the fuels and solid biofuels with various types of additives, often with materials having features typical of hazardous waste. This process is carried out both at the production stage of these fuels, e.g., the addition of waste in the form of ground plastics or waste furniture boards to wooden pellets (Rưžičková et al. 2018), as well as during the combustion process in individual heating devices (Reyna-Bensusan et al. 2018). Such activities constitute a significant problem in the scope of protecting the environment (Gulletta et al. 2001) and reducing the emissions of pollutants into the environment (Ross et al. 2002; Zhang et al. 2011; Solorzano-Ochoaa et al. 2012; Maasikmets et al. 2016; Edo et al. 2018), and those responsible for this practice are in breach of legal provisions. In Poland, the basic legal act regulating issues related to waste management is the Act of 14 December 2012 on Waste (consolidated text, Journal of Laws of 2019, item 701, as amended). In addition, the combustion of unadulterated waste can lead to several adverse health effects including diseases of the respiratory and circulatory systems and allergic hypersensitivity reactions (Das et al. 2018). A significant portion of the pollutants emitted are organic compounds such as polycyclic aromatic hydrocarbons (PAHs), which are known to be mutagenic and carcinogenic (Johansson et al. 2004; Naeher et al. 2007).

Globally, more than 62 billion tonnes of municipal wastes are burnt in an uncontrolled manner by users during open burning activities according to estimates (Wiedinmyer et al. 2014). However, these wastes should be directed to landfills or subjected to a recovery process in accordance with applicable laws.

The municipal waste used to generate heat contains a number of organic compounds and toxic metals that can be released during the combustion 
process from individual boilers or furnaces and contaminant the atmosphere, where these chemicals may pose threats to the environment and public health (Ross et al. 2002; Zhang et al. 2011; Solorzano-Ochoaa et al. 2012; Maasikmets et al. 2016; Edo et al. 2018). In addition, following the combustion process, furnace waste can have different petrographic and chemical properties depending on the formulation of accessible solid fuels, burning techniques, and heating devices used. In terms of chemical properties, furnace waste from individual furnaces and boilers consists mainly of the mineral part in the form of various oxides (e.g., $\mathrm{Na}_{2} \mathrm{O}, \mathrm{MgO}, \mathrm{Al}_{2} \mathrm{O}_{3}, \mathrm{SiO}_{2}, \mathrm{P}_{2} \mathrm{O}_{5}, \mathrm{~K} 2 \mathrm{O}, \mathrm{CaO}, \mathrm{TiO}_{2}$, and $\mathrm{Fe}_{2} \mathrm{O}_{3}$ ) and contaminants such as elements occurring in trace amounts (e.g., heavy metals) (Iwanek et al. 2002; Morselli et al. 2002).

It should be noted that all possible methods in the area of identification of waste incineration in individual heating devices must prove with an acceptable probability that the physicochemical properties of the collected samples (e.g., exhaust gases, soot or ash) significantly differ from the properties of samples derived from the combustion of pure fuel (biomass, hard coal or mixtures thereof). The methods from the point of view of the test object and the used research technique can be divided into several groups: visual evaluation of combustion waste, exhaust gas testing, soot analysis, and chemical testing of combustion waste.

On the basis of the literature review, several authors point to the identification of the process of municipal waste incineration in central heating furnaces using the methods of chemical testing of furnace waste. One of them is a method based on chemical testing of metals as indicators of municipal waste combustion, which has been indicated by several authors (Horak et al. 2019, Szulik 2018). This method appears to be effective for a significant concentration of unauthorized additive. However, with a small amount of the additive, it may not be sufficient for the intended purpose, because the changes in individual elements indicated as indicators will be small and will not allow to make a clear conclusion. In addition, work is underway on methods based on testing of plastic residues and the concentration of polycyclic aromatic hydrocarbons (PAHs) in ash samples (Muzyka et al. 2019).

The method based on exhaust gas testing is difficult to implement under real conditions and the results of such tests will not always allow to make a right decision. Based on the performed research, it was observed that combustion of fuels under uncontrolled conditions promotes the emission of persistent organic pollutants, especially dioxins and furans (PCDD/F) (Grochowalski 2008) and the emission of dust containing numerous organic compounds adsorbed on it (Gaffney et al. 2009). An interesting solution to inspection of individual heating devices is the use of drones. Most often, these tests are used for the initial selection of suspicious boilers.

The soot testing seems promising due to its significant ability to absorb of contaminants. Unfortunately, for routine inspections of individual heating devices, it may not be effective due to combining several heating devices into one chimney draught. 
Knowledge of the chemical composition of furnace waste as well as petrographic studies will allow us to better understand the environmental and health impacts stemming from the use of solid energy carries for the generation of heat. The aim of this research was to develop a method that can identify the sources of furnace waste from indicator data on the furnace waste, i.e., whether it was created as a result of burning hard coal, solid biofuels, or hard coal composites of solid biofuels and municipal waste.

The practice of burning solid fuels in combination with municipal waste is illegal in many areas because this can lead to the release of harmful atmospheric pollutants. In this study, we propose a comprehensive method for identifying such activities through the examination of furnace waste. Furnace waste was subjected to both chemical and petrographic tests. The presence of bones, metals, and plastics in the samples was indicative of municipal waste use. The application of such a testing approach to identify these illegal practices can help to reduce harmful atmospheric emissions.

\section{RESEARCH MATERIAL}

The performed research was conducted with furnace wastes obtained from end users who employed the burning process in individual heating devices. The research required that the samples used during the laboratory tests were anonymous. The furnace wastes were collected by local government units, which performed inspections of individual heating boilers when there was a suspicion that the ban on municipal waste incineration had been violated.

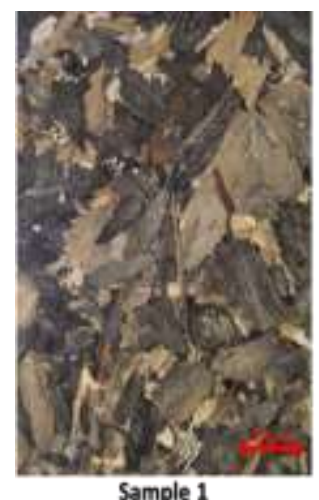

Sample 1

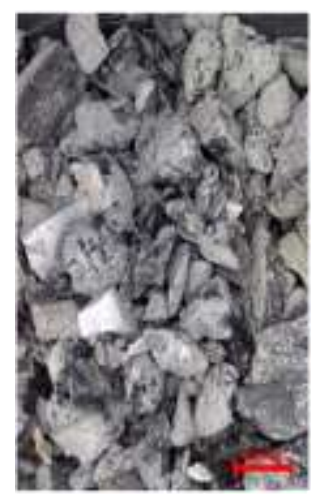

Sample 4

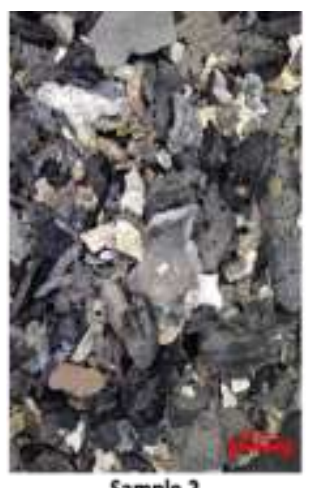

Sample 2

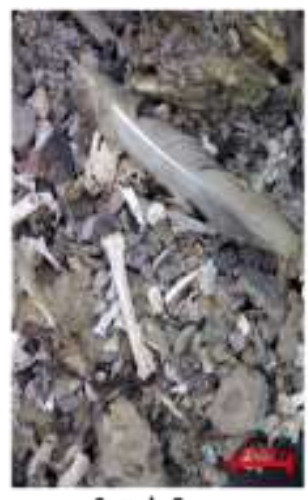

Sample 5
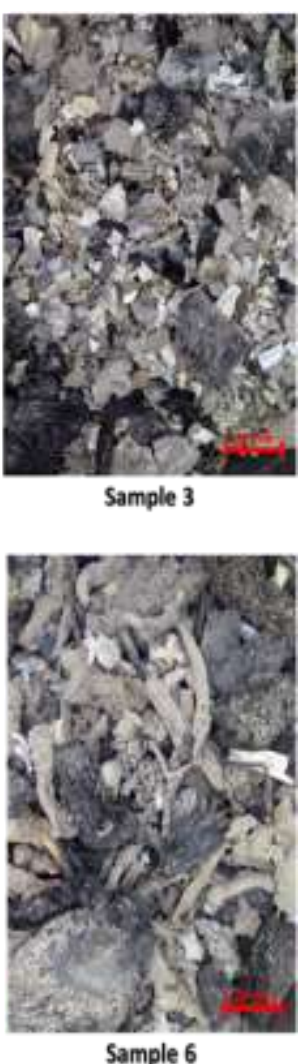

Sample 6

Fig. 1 Furnace waste from end users employing the combustion process

(samples 1 to 6 ) 
During the sampling, the principle of representativeness of the samples was ensured and proper care was taken to avoid contamination of the samples. After sampling, the samples were secured in stainless steel containers and provided with a unique, protective seal, and then, the samples were forwarded to the testing laboratory. Photographs 1 to 6 present the general appearance of the research materials used in the tests (Fig. 1).

Samples were characterized by a variety of structures and graining patterns. In some samples, various types of unburnt municipal waste residues such as bones were visible. Directly after receiving the research material, evaluations of its morphological characteristics (e.g., color, smell, physical form, and sieve analysis for $\leq 4.0 \mathrm{~mm}$ and $>4.0 \mathrm{~mm}$ fractions) were performed to identify the original characteristics of the municipal waste (Table 1).

Table 1 External characterization of furnace waste samples with the sieve analysis

\begin{tabular}{|c|c|c|c|c|c|c|c|c|}
\hline \multirow{2}{*}{ No } & \multirow{2}{*}{\multicolumn{2}{|c|}{$\begin{array}{l}\text { Tested feature/ } \\
\text { Parameter }\end{array}$}} & \multicolumn{6}{|c|}{ Sample } \\
\hline & & & 1 & 2 & 3 & 4 & 5 & 6 \\
\hline 1 & Color & & $\begin{array}{l}\text { Black/ } \\
\text { Brown }\end{array}$ & $\begin{array}{l}\text { Black/ } \\
\text { Gray }\end{array}$ & \multicolumn{2}{|c|}{ Black/Gray Gray } & Dark gray & Gray \\
\hline 2 & Smell & & $\begin{array}{l}\text { Burned } \\
\text { biomass }\end{array}$ & \multicolumn{5}{|c|}{ No characteristic odor } \\
\hline 3 & Physical & orm & solid & solid & solid & solid & solid & solid \\
\hline \multirow{2}{*}{4} & \multirow{2}{*}{$\begin{array}{l}\text { Sieve } \\
\text { Analysis } \\
\text { weight } \\
\text { [g], } \\
\text { percent } \\
\text { age } \\
\text { fraction } \\
{[\%]} \\
\end{array}$} & $\begin{array}{l}\leq 4.0 \\
\mathrm{~mm}\end{array}$ & $\begin{array}{l}\text { weight: } \\
704.5 \\
\text { fraction: } \\
93.5\end{array}$ & $\begin{array}{l}\text { weight: } \\
1874.5 \\
\text { fraction: } \\
89.5\end{array}$ & $\begin{array}{l}\text { weight: } \\
983.0 \\
\text { fraction: } \\
56.55\end{array}$ & $\begin{array}{l}\text { weight: } \\
743.8 \\
\text { fraction: } \\
57.3\end{array}$ & $\begin{array}{l}\text { weight: } \\
794.7 \\
\text { fraction: } \\
74.5\end{array}$ & $\begin{array}{l}\text { weight: } \\
842.8 \\
\text { fraction: } \\
75.61\end{array}$ \\
\hline & & $\begin{array}{l}>4.0 \\
\mathrm{~mm}\end{array}$ & $\begin{array}{l}\text { weight: } \\
48.9 \\
\text { fraction: } \\
6.5\end{array}$ & $\begin{array}{l}\text { weight: } \\
220.3 \\
\text { fraction: } \\
10.5\end{array}$ & $\begin{array}{l}\text { weight: } \\
755.4 \\
\text { fraction: } \\
43.45\end{array}$ & $\begin{array}{l}\text { weight: } \\
554.7 \\
\text { fraction: } \\
42.7\end{array}$ & $\begin{array}{l}\text { weight: } \\
272.5 \\
\text { fraction: } \\
25.5\end{array}$ & $\begin{array}{l}\text { weight: } \\
271.8 \\
\text { fraction: } \\
24.39\end{array}$ \\
\hline 5 & Sample we & ight [g] & 753.4 & 2094.8 & 1738.4 & 1298.5 & 1067.2 & 1114.6 \\
\hline
\end{tabular}

\section{Methods}

In the first stage, the samples were subjected to macroscopic studies to identify the presence of unburnt, overburdened substances originating from municipal waste. These evaluations were performed on mechanically unchanged samples, i.e., samples in the delivered condition. Afterward, the samples were subjected to analyses to determine the percentage composition of oxides $\left(\mathrm{Na}_{2} \mathrm{O}\right.$, $\mathrm{MgO}, \mathrm{Al}_{2} \mathrm{O}_{3}, \mathrm{SiO}_{2}, \mathrm{P}_{2} \mathrm{O}_{5}, \mathrm{~K} 2 \mathrm{O}, \mathrm{CaO}, \mathrm{TiO}_{2}$, and $\mathrm{Fe}_{2} \mathrm{O}_{3}$ ) and the concentrations of elements occurring in trace amounts ( $\mathrm{Ba}, \mathrm{Zn}, \mathrm{Cd}, \mathrm{Cu}, \mathrm{Pb}, \mathrm{Zn}, \mathrm{Sb}$, and $\mathrm{Zr}$ ). Petrographic studies were carried out based on the methodology developed within the working group of the International Committee for Coal and Organic Petrology (Suárez-Ruiz and Valentim 2015; Suárez-Ruiz et al. 2017) with the modifications discussed briefly below.

\section{Chemical studies}

First, the furnace wastes were ground to a grain size below $0.2 \mathrm{~mm}$. Then, the samples were grounded to grain size fractions below $75 \mu \mathrm{m}$ and were treated by a microwave digestion process that used a $30 \%$ hydrogen peroxide $\left(\mathrm{H}_{2} \mathrm{O}_{2}\right)$ with a mixture of acids such as $\mathrm{HCl}, \mathrm{HF}$, and $\mathrm{HNO}_{3}$. The indicated procedure 
allowed us to dissolve the samples effectively within a comparatively short time, and low amounts of reagents were needed in relation to open-space mineralization. After completing the process of mineralization, hydrofluoric acid (HF) present in the test solution was neutralized with the addition of $5 \%$ boric acid $\left(\mathrm{H}_{3} \mathrm{BO}_{3}\right)$. The solutions obtained in this way constituted the testing material. Afterward, the further examination of the samples was conducted by the use of ICP-AES (inductively coupled plasma atomic emission spectrometry) techniques.

The applied research method was subjected to a validation process in order to confirm its reasonable application to the specified tests. The usefulness of the method was confirmed, and the results from the method were characterized by the designated uncertainty.

\section{Petrographic studies}

First, the furnace wastes were ground to a grain size below $1.25 \mathrm{~mm}$, and then, these samples were poured into $40 \mathrm{~mm}$ diameter molds of screened material with a Struers SpeciFix-20 Kit. After removing the mold samples, they were subjected to a grinding process on water-resistant abrasive paper with successive grain sizes of 800,1200 , and 2500 , and at the final stage, the samples were polished on a polishing disk. After grinding, the samples were washed first under running water and then with distilled water and dried. The samples thus obtained were subjected to light-reflected white, polarized, and fluorescent light.

\section{RESULTS AND DISCUSSION}

The results of macroscopic examinations are presented in Table 2. These tests were carried out before the preparation of the samples for chemical and petrographic research. This was necessary to preserve the unchanged structures of the material. For example, all of the preparation processes caused a change in the grain size of the research material, which would have impeded the identification of the original macroscopic structures indicating the presence of materials derived from municipal waste. These structures were identified in fractions $\leq 4.0 \mathrm{~mm}$.

Table 2 Macroscopic research results for waste samples subjected to examinations

\begin{tabular}{llllllll}
\hline & \multicolumn{7}{c}{ Sample } \\
\cline { 2 - 8 } MACROSCOPIC & $\mathbf{1}$ & $\mathbf{2}$ & $\mathbf{3}$ & & $\mathbf{4}$ & $\mathbf{5}$ & $\mathbf{6}$ \\
\cline { 2 - 8 } REASERCH & - & - & metallic & metallic & metallic & metallic & metallic \\
\cline { 2 - 8 } & metallic & - & - & - & - & glass & glass \\
\cline { 2 - 8 } & plastics & - & metallic Zn & metallic Zn & - & - & plastics \\
& - & - & metallic Al & - & plastics & plastics \\
\cline { 2 - 7 } & - & & & & & - & metallic Zn \\
\hline
\end{tabular}

The studies carried out confirmed the presence of bones in sample numbers 5 and 6, and these bones were derived from municipal wastes; hence, these results were indicative of the doping of fuel materials by kitchen wastes (as 
broadly understood). In all of the samples, the presence of metal residues was noted; in particular, the existence of metallic zinc $(\mathrm{Zn})$ was detected in sample numbers 2,3 , and 6 , and the existence of metallic aluminum ( $\mathrm{Al}$ ) was detected in sample numbers 3 and 6 .

In sample numbers 1, 4, 5, and 6, plastic residues were identified, which clearly indicates that municipal waste was added to the fuel material.

The results of the chemical tests are presented along with the measurement uncertainty. The uncertainty of measurement was determined at the stage of validation of the test method as a non-negative parameter characterizing the dispersion of the value assigned to the mesurand. At the stage of validation of the applied test method, the following features were determined:

- precision under repeatability and reproducibility conditions,

- recovery,

- $\quad$ limit of quantification (LOQ),

- limit of detection (LOD),

- method linearity, and

- uncertainty of measurement, which is presented as an extended value for the expansion coefficient $k=2$, which means a confidence level of approximately $95 \%$.

The results of chemical tests are presented in Table 3 . The highest concentration of zinc $(\mathrm{Zn})$ was observed for sample numbers 2,3 , and 6 , and these data confirm the macroscopic examination results in which zinc $(\mathrm{Zn})$ was identified in the same samples. The highest concentrations of antimony (Sb), zinc $(\mathrm{Zn})$, and lead $(\mathrm{Pb})$ were observed in sample number 6 , in which macroscopic and petrographic studies indicated the presence of plastics. The elevated concentrations of antimony $(\mathrm{Sb})$, zinc $(\mathrm{Zn})$, and lead $(\mathrm{Pb})$ could have been caused by the use of chemical compounds containing these metals as additives to reduce the flammability of plastics or to prevent their decomposition. The furnace waste from sample number 1 was mainly derived from the combustion of solid biomass as indicated by the concentration of $\mathrm{K}_{2} \mathrm{O}$ at the level of $15.60 \%$ (Table 3), which is characteristic for biomass waste. This was confirmed by the macroscopic photograph of sample number 1 (Figure 1), on which the remnants of unburned biomass were visualized.

Table 3 Chemical properties of waste samples subjected to examinations

\begin{tabular}{|c|c|c|c|c|c|c|c|}
\hline \multirow{2}{*}{ Parameter } & \multirow{2}{*}{ Unit } & \multicolumn{6}{|c|}{ Sample } \\
\hline & & 1 & 2 & 3 & 4 & 5 & 6 \\
\hline $\mathrm{Zn}$ & $\mathrm{mg} / \mathrm{kg}$ & $\begin{array}{l}2223.00 \\
\pm 400.14\end{array}$ & $\begin{array}{l}36,235.00 \\
\pm 6522.30\end{array}$ & $\begin{array}{l}113,858.00 \\
\pm 20,494.44\end{array}$ & $\begin{array}{l}1055.00 \\
\pm 189.90\end{array}$ & $\begin{array}{l}893.00 \\
\pm 160.74\end{array}$ & $\begin{array}{l}66,694.00 \\
\pm 12,004.92\end{array}$ \\
\hline $\mathrm{Ba}$ & $\mathrm{mg} / \mathrm{kg}$ & $\begin{array}{l}4888.00 \\
\pm 1026.48\end{array}$ & $\begin{array}{r}10,108.00 \\
\pm 2122.68 \\
\end{array}$ & $\begin{array}{l}8985.00 \\
\pm 1886.85 \\
\end{array}$ & $\begin{array}{l}124.1 \\
\pm 26.0\end{array}$ & $\begin{array}{l}647.1 \\
\pm 135.9\end{array}$ & $\begin{array}{l}2814.00 \\
\pm 590.94 \\
\end{array}$ \\
\hline $\mathrm{Cd}$ & $\mathrm{mg} / \mathrm{kg}$ & $<4$ & $\begin{array}{l}578.9 \\
\pm 144.5 \\
\end{array}$ & $<4$ & $<4$ & $<4$ & $\begin{array}{l}7.0 \\
\pm 1.8\end{array}$ \\
\hline $\mathrm{Sb}$ & $\mathrm{mg} / \mathrm{kg}$ & $\begin{array}{l}25.1 \\
\pm 6.7 \\
\end{array}$ & $\begin{array}{l}19.6 \\
\pm 5.3 \\
\end{array}$ & $<4$ & $<4$ & $\begin{array}{l}10.0 \\
\pm 2.7 \\
\end{array}$ & $\begin{array}{l}155.1 \\
\pm 41.85 \\
\end{array}$ \\
\hline $\mathrm{Pb}$ & $\mathrm{mg} / \mathrm{kg}$ & $\begin{array}{l}58.0 \\
\pm 13.9 \\
\end{array}$ & $\begin{array}{l}578.9 \\
\pm 138.9 \\
\end{array}$ & $\begin{array}{l}275.0 \\
\pm \quad 66.0 \\
\end{array}$ & $\begin{array}{l}124.1 \\
\pm 29.8 \\
\end{array}$ & $\begin{array}{l}1298.0 \\
\pm 311.52 \\
\end{array}$ & $\begin{array}{l}1746.0 \\
\pm 419.0 \\
\end{array}$ \\
\hline $\mathrm{Zr}$ & $\mathrm{mg} / \mathrm{kg}$ & $\begin{array}{l}88.1 \\
\pm 21.1 \\
\end{array}$ & $\begin{array}{l}33.2 \\
\pm 8.0 \\
\end{array}$ & $\begin{array}{l}22.6 \\
\pm 5.4 \\
\end{array}$ & $\begin{array}{l}15.3 \\
\pm 3.7 \\
\end{array}$ & $\begin{array}{l}62.8 \\
\pm 15.1 \\
\end{array}$ & $\begin{array}{l}17.2 \\
\pm 4.1 \\
\end{array}$ \\
\hline $\mathrm{Cu}$ & $\mathrm{mg} / \mathrm{kg}$ & $\begin{array}{l}190.4 \\
\pm 45.7 \\
\end{array}$ & 439.0 & $\begin{array}{l}580.0 \\
\pm 139.2 \\
\end{array}$ & 146.0 & 273.8 & $\begin{array}{l}130,934.0 \\
\pm 31,424.2 \\
\end{array}$ \\
\hline
\end{tabular}




\begin{tabular}{|c|c|c|c|c|c|c|c|}
\hline & & & 105 & & 35.0 & 65 & \\
\hline $\mathrm{Ti}$ & $\mathrm{mg} / \mathrm{kg}$ & $\begin{array}{r}112,133 \\
\pm 19,062 \\
\end{array}$ & $\begin{array}{r}49,910 \\
\pm 8484 \\
\end{array}$ & $\begin{array}{l}27,992 \\
\pm 4758 \\
\end{array}$ & $\begin{array}{r}25,703 \\
\pm 4369 \\
\end{array}$ & $\begin{array}{l}4303 \\
\pm 731 \\
\end{array}$ & $\begin{array}{r}37,193 \\
\pm 6322 \\
\end{array}$ \\
\hline $\mathrm{SO}_{3}$ & $\%$ & $\begin{array}{l}1.42 \\
\pm 0.31 \\
\end{array}$ & $\begin{array}{l}1.86 \\
\pm 0.41 \\
\end{array}$ & $\begin{array}{l}1.56 \\
\pm 0.34 \\
\end{array}$ & $\begin{array}{l}1.22 \\
\pm 0.27 \\
\end{array}$ & $\begin{array}{l}1.66 \\
\pm 0.37 \\
\end{array}$ & $\begin{array}{l}2.15 \\
\pm 0.47 \\
\end{array}$ \\
\hline $\mathrm{P}_{2} \mathrm{O}_{5}$ & $\%$ & $\begin{array}{l}1.22 \\
\pm 0.18 \\
\end{array}$ & $\begin{array}{l}0.78 \\
\pm 0.12 \\
\end{array}$ & $\begin{array}{l}1.11 \\
\pm 0.17 \\
\end{array}$ & $\begin{array}{l}0.55 \\
\pm 0.08 \\
\end{array}$ & $\begin{array}{l}0.87 \\
\pm 0.13 \\
\end{array}$ & $\begin{array}{l}0.71 \\
\pm 0.11 \\
\end{array}$ \\
\hline $\mathrm{MgO}$ & $\%$ & $\begin{array}{l}3.57 \\
\pm 0.57\end{array}$ & $\begin{array}{l}2.25 \\
\pm 0.36\end{array}$ & $\begin{array}{l}2.87 \\
\pm 0.46\end{array}$ & $\begin{array}{l}4.20 \\
\pm 0.67\end{array}$ & $\begin{array}{l}2.54 \\
\pm 0.41\end{array}$ & $\begin{array}{l}1.98 \\
\pm 0.32\end{array}$ \\
\hline $\mathrm{CaO}$ & $\%$ & $\begin{array}{l}8.7 \\
\pm 1.5 \\
\end{array}$ & $\begin{array}{l}16.5 \\
\pm 2.8 \\
\end{array}$ & $\begin{array}{l}11.3 \\
\pm 1.9 \\
\end{array}$ & $\begin{array}{l}25.4 \\
\pm 4.3 \\
\end{array}$ & $\begin{array}{l}30.5 \\
\pm 5.2 \\
\end{array}$ & $\begin{array}{l}15.1 \\
\pm 2.6 \\
\end{array}$ \\
\hline $\mathrm{TiO}_{2}$ & $\%$ & $\begin{array}{l}18.70 \\
\pm 3.18 \\
\end{array}$ & $\begin{array}{l}8.33 \\
\pm 1.42 \\
\end{array}$ & $\begin{array}{l}4.67 \\
\pm 0.79 \\
\end{array}$ & $\begin{array}{l}4.29 \\
\pm 0.73 \\
\end{array}$ & $\begin{array}{l}0.72 \\
\pm 0.12 \\
\end{array}$ & $\begin{array}{l}6.20 \\
\pm 1.05 \\
\end{array}$ \\
\hline $\mathrm{Al}_{2} \mathrm{O}_{3}$ & $\%$ & $\begin{array}{l}5.80 \\
\pm 1.33 \\
\end{array}$ & $\begin{array}{r}16.50 \\
\pm 3.80 \\
\end{array}$ & $\begin{array}{l}18.70 \\
\pm 4.30 \\
\end{array}$ & $\begin{array}{l}13.78 \\
\pm 3.17 \\
\end{array}$ & $\begin{array}{l}19.65 \\
\pm 4.52 \\
\end{array}$ & $\begin{array}{l}8.20 \\
\pm 1.89 \\
\end{array}$ \\
\hline $\mathrm{Na}_{2} \mathrm{O}$ & $\%$ & $\begin{array}{l}0.80 \\
\pm 0.17 \\
\end{array}$ & $\begin{array}{l}5.50 \\
\pm 1.16 \\
\end{array}$ & $\begin{array}{l}4.80 \\
\pm 1.01 \\
\end{array}$ & $\begin{array}{l}1.81 \\
\pm 0.38 \\
\end{array}$ & $\begin{array}{l}1.54 \\
\pm 0.32 \\
\end{array}$ & $\begin{array}{l}2.40 \\
\pm 0.50 \\
\end{array}$ \\
\hline $\mathrm{K}_{2} \mathrm{O}$ & $\%$ & $\begin{array}{l}15.60 \\
\pm 3.74 \\
\end{array}$ & $\begin{array}{l}0.70 \\
\pm 0.17 \\
\end{array}$ & $\begin{array}{l}1.50 \\
\pm 0.36 \\
\end{array}$ & $\begin{array}{l}2.21 \\
\pm 0.53 \\
\end{array}$ & $\begin{array}{l}1.48 \\
\pm 0.36 \\
\end{array}$ & $\begin{array}{l}7.50 \\
\pm 1.80 \\
\end{array}$ \\
\hline $\mathrm{SiO}_{2}$ & $\%$ & $\begin{array}{l}22.4 \\
\pm 3.4 \\
\end{array}$ & $\begin{array}{l}29.1 \\
\pm 4.4 \\
\end{array}$ & $\begin{array}{l}32.5 \\
\pm 4.9 \\
\end{array}$ & $\begin{array}{l}41.5 \\
\pm 6.2 \\
\end{array}$ & $\begin{array}{l}39.5 \\
\pm 5.9 \\
\end{array}$ & $\begin{array}{l}24.2 \\
\pm 3.6 \\
\end{array}$ \\
\hline $\begin{array}{l}\text { non- } \\
\text { combustible } \\
\text { fraction }\end{array}$ & $\%$ & $\begin{array}{l}75.9 \\
\pm 0.8\end{array}$ & $\begin{array}{l}88.7 \\
\pm 0.9\end{array}$ & $\begin{array}{l}92.5 \\
\pm 1.0\end{array}$ & $\begin{array}{l}58.1 \\
\pm 0.6\end{array}$ & $\begin{array}{l}91.1 \\
\pm 1.0\end{array}$ & $\begin{array}{l}93.1 \\
\pm 1.1\end{array}$ \\
\hline $\begin{array}{l}\text { combustible } \\
\text { fraction }\end{array}$ & $\%$ & $\begin{array}{l}24.1 \\
\pm 0.3 \\
\end{array}$ & $\begin{array}{l}11.3 \\
\pm 0.2 \\
\end{array}$ & $\begin{array}{l}7.5 \\
\pm 0.1 \\
\end{array}$ & $\begin{array}{l}41.9 \\
\pm 0.5 \\
\end{array}$ & $\begin{array}{l}8.9 \\
\pm 0.1 \\
\end{array}$ & $\begin{array}{l}6.9 \\
\pm 0.1 \\
\end{array}$ \\
\hline
\end{tabular}

The results of the petrographic research are presented in Table 4. On the basis of these studies, it can be stated that the sample number 1 was the least thermally transformed testing material (Table 4), as large concentrations of biomass were observed; it also had the highest content of $\mathrm{K}_{2} \mathrm{O}$ as previously demonstrated in Table 2. In all of the samples (Table 4), the presence of metals, mainly iron ( $\mathrm{Fe}$ ) and other common metals, was observed (Figure 2), which confirms the macroscopic examination results in which metals were also detected (Table 2). The petrographic studies confirmed the presence of plastics in sample numbers 3 and 6 (Figure 3). Macroscopic examinations (Table 1) showed the presence of plastics in sample numbers $1,4,5$, and 6 .

Table 4 Petrographic properties of wastes samples subjected to examinations

\begin{tabular}{|c|c|c|c|c|c|c|c|c|c|}
\hline \multirow{2}{*}{\multicolumn{3}{|c|}{ Parameter }} & \multirow{2}{*}{ Unit } & \multicolumn{6}{|c|}{ Sample } \\
\hline & & & & 1 & 2 & 3 & 4 & 5 & 6 \\
\hline \multirow{11}{*}{$\begin{array}{l}\text { Organic } \\
\text { fraction }\end{array}$} & \multicolumn{2}{|c|}{ Burned (thermal transformed) } & $\%$ & 9.2 & 62.4 & 10.8 & 77.6 & 62.4 & 21.4 \\
\hline & \multicolumn{2}{|c|}{ Un-burned } & $\%$ & 3.6 & 1.6 & 2.4 & 6.8 & 1.6 & 0.6 \\
\hline & \multicolumn{2}{|l|}{ Fused } & $\%$ & 37.5 & 40.6 & 21.2 & 72.5 & 34.9 & 41.8 \\
\hline & \multicolumn{2}{|l|}{ Unfused } & $\%$ & 34.4 & 56.9 & 60.6 & 19.4 & 27.9 & 58.2 \\
\hline & Structure & Dense/Massive & $\%$ & 59.4 & 69.4 & 72.7 & 82.9 & 51.2 & 83.6 \\
\hline & Morphology & Porous/Vesiculate & $\%$ & 12.5 & 28.1 & 9.1 & 9.0 & 11.6 & 12.7 \\
\hline & \multirow{2}{*}{$\begin{array}{l}\text { Optical } \\
\text { texture }\end{array}$} & Isotropic & $\%$ & 71.9 & 96.9 & 78.8 & 91.9 & 62.8 & 96.4 \\
\hline & & Anisotropic & $\%$ & 0 & 0.6 & 3 & 0 & 0 & 0 \\
\hline & \multirow{3}{*}{ Origin } & Coal & $\%$ & 18.8 & 37.5 & 9.1 & 69.2 & 48.8 & 40.0 \\
\hline & & Biomass & $\%$ & 81.3 & 62.5 & 90.9 & 31.8 & 48.8 & 60.0 \\
\hline & & Other & $\%$ & 0 & 0 & 0 & 0 & 0 & 0 \\
\hline \multirow{7}{*}{\multicolumn{2}{|c|}{ Inorganic fraction }} & Total metallic & $\%$ & 3.6 & 5.6 & 2.8 & 3.6 & 5.6 & 9.6 \\
\hline & & Metallic Fe & $\%$ & 3.2 & 2.5 & 1.2 & 2.0 & 2.4 & 4.8 \\
\hline & & Metallic Al & $\%$ & 0.0 & 1.2 & 0.8 & 0.0 & 0.0 & 2.8 \\
\hline & & Metallic Zn & $\%$ & 0.0 & 0.0 & 0.0 & 0.0 & 0.0 & 0.4 \\
\hline & & Total non-metallic & $\%$ & 83.6 & 30.4 & 84.0 & 12.0 & 30.4 & 68.4 \\
\hline & & Glass & $\%$ & 0 & 0 & 0 & 0 & 0 & 2 \\
\hline & & Plastics & $\%$ & 0.0 & 0.0 & 0.4 & 0.0 & 0.0 & 0.8 \\
\hline
\end{tabular}



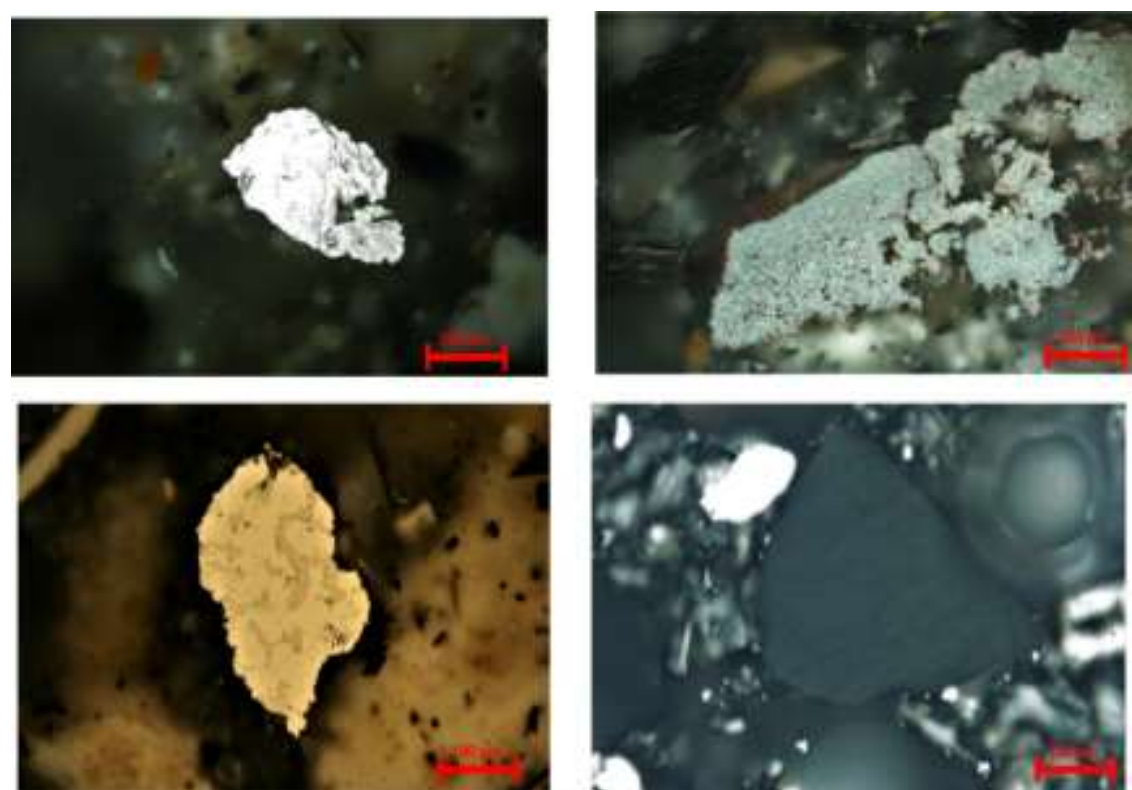

Fig. 2 Identification of metals based on petrographic studies
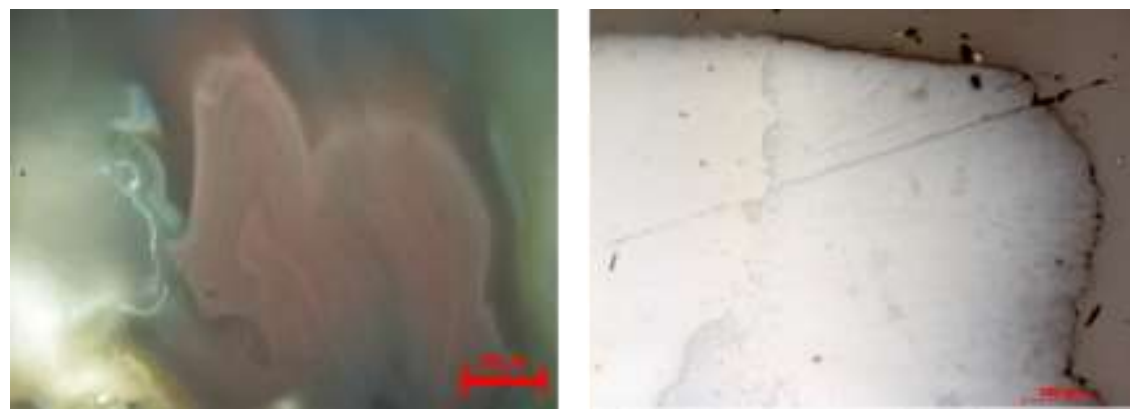

Fig. 3 Identification of plastics based on petrographic studies

The presented research will be an input to the system being developed for identifying additives and admixtures in heating materials and their combustion products. As part of the research problem, a database for pure fuels and a catalogue of pollution images are being developed.

\section{CONCLUSIONS}

On the basis of macroscopic, chemical, and petrographic research, it is possible to identify those furnace wastes that have been produced using the combustion processes of individual heating devices by adding illicit substances to the fuel such as municipal waste. For some samples, macroscopic studies confirmed the chemical or petrographic tests and vice versa. The combination of the above-mentioned research methodoliges offers a rapid and unambiguous method for identifying unauthorized contaminants in furnace wastes from individual heating devices. The developed method should contribute to the enforcement of laws banning the process of municipal waste combustion. Additional, the synergystic effect of macroscopic, chemical, and petrographic analyses can give a comprehensive overview of the materials being tested. Importantly, the use of all three methods eliminates the risks of mistakes because the methods complement each other. 
With regard to the chemical analyses conducted, significant increases in the concentrations of heavy metals in furnace wastes were observed, arising from the co-incineration of municipal waste; this was in contrast to the waste generated as a result of burning solid fuels. The highest zinc $(\mathrm{Zn})$ concentration was observed for sample number 3 , while the highest lead $(\mathrm{Pb})$ and copper $(\mathrm{Cu})$ concentrations were recorded for sample number 6 . The petrographic analyses performed confirmed the presence of residual structures after the combustion of plastics, glass, and metals, which was indicative of the process of municipal waste incineration.

\section{ACKNOWLEDGMENTS}

This work was carried out as part of the first edition of the program implementation doctorate realized by the Ministry of Science and Higher Education, Republic of Poland.

\section{Disclosure statement}

There are no competing interests to declare.

\section{REFERENCES}

Reyna-Bensusan N., Wilson D. C., Smith S. R., (2018), Uncontrolled burning of solid waste by households in Mexico is a significant contributor to climate change in the country, Environmental Research 163, pp. 280-288

Gulletta B. K., Lemieuxa P. M., Lutes C., Winterrowd C. K. Winters D. L. (2001), Emissions of PCDD/F from uncontrolled, domestic waste burning, Chemosphere, 43, pp. 721-725

Solorzano-Ochoaa G., A.de la Rosaa D., Maiz-Larraldeb P., K.Gullettc B., G.Tabord D., Touatid A., Wyrzykowska-Ceradinid B., Fiedlere H., Abelf T., F. Carroll Jr.f W. (2012), Open burning of household waste: Effect of experimental condition on combustion quality and emission of PCDD, PCDF and PCB, Chemosphere 87, 9, pp. 1003-1008

Edo M., Ortuño N., Persson P., A.Conesa J., Janssona S. (2018), Emissions of toxic pollutants from co-combustion of demolition and construction wood and household waste fuel blends, Chemosphere 203, pp. 506-513

Ross, A B, Jones J M, Chaiklangmuang S, Pourkashanian M, Williams A, Kubica K. (2002), Measurement and Prediction of the Emission of Pollutant from the Combustion of Coal and Biomass in a Fixed Bed Furnace, Fuel 81, pp. 571-82

Maasikmets M., Kupria H., Teinema E., Vainumäe K., Arumäe T., Rootsa O., Kimmel V. (2016), Emissions from burning municipal solid waste and wood in domestic heaters, Atmospheric Pollution Research 7, pp. 438-446

Zhang T., Fiedler H., Yua G., Solorzano Ochoa G., William F.Carroll Jr. W., K.Gullette B., Marklund S., Touati A. (2011), Emissions of unintentional persistent organic pollutants from open burning of municipal solid waste from developing countries, Chemosphere 84, pp. 994-1001

Das B., Bhave P., Sapkota A., M. Byanjua R. (2018), Estimating emissions from open burning of municipal solid waste in municipalities of Nepal, Waste Management 79, pp. $481-490$

Johansson L.S., Leckner B., Gustavsson L., Cooper D., Tullin C., Potter A., (2004), Emission characteristics of modern and old-type residential boilers fired with wood logs and wood pellets, Atmos. Environ. 38 pp. 4183-4195

Naeher L.P., Brauer M., Lipsett M., Zelikoff J.T., Simpson C.D., Koenig J.Q., Smith K.R. (2007), Woodsmoke health effects: a review, Inhalation Toxicology, 19 pp. 67106 
Wiedinmyer. C., Yokelson. R.J., Gullett. B.K. (2014), Global emissions of trace gases, particulate matter and hazardous air pollutants from open burning of domestic waste, Environ. Sci. Technol. 48, pp. 9523-9530

Růžičková J., Raclavskáa H., Kucbela M., Raclavský K., Šafářa M., Švédová B. (2018), The possibilities to identify combusted fuel based on an analysis of ash from local heating, Journal of Environmental Management, 219, pp. 269-276

Iwanek P., Jelonek I., Mirkowski Z. (2008), Wstępne badania popiołów z kotła fluidalnego w aspekcie ich zagospodarowania, Gospodarka Surowcami Mineralnymi. 24. Z. 4/4

Morselli L., Passarini F., Bartoli M. (2002), The environmental fate of heavy metals arising from a MSW incineration plant, Waste Manage. 22: pp. 875-881.

Horák J., Kuboňová L., Bajer S., Dej M., Hopan F., Krpec K., Ochodek T., (2019), Composition of ashes from the combustion of solid fuels and municipal waste in households, Journal of Environmental Management, 248, pp. 109-269

Szulik W., (2018), Physicochemical properties of furnace wastes for co-combustion of solid fuels with municipal waste and oil wastes, Archives of Waste Managementand Environmental Protection, 20, 4. pp. 1-8

Muzyka R., Chrubasik M., Pogoda M. et al. (2019) Py-GC-MS and PCA Analysis Approach for the Detection of Illegal Waste Combustion Processes In Central Heating Furnaces, Chromatographia, 82, pp. 1101-1109

Grochowalski A., Konieczyński A., (2008) PCDDs/PCDFs, dl-PCBs and HCB in the flue gas from coal fired CFB boilers, Chemosphere, 73, 1, pp. 97-103

Gaffney J., Marley N., (2009) The impacts of combustion emissions on air quality and climate - From coal to biofuels and beyond, Atmospheric Environment, 43, 1, pp. 23-36

Suárez-Ruiz, I., Valentim, B., Borrego, A.G., Bouzinos, A., Flores, D., Kalaitzidis, S., Malinconico, M.L. Marques, M. Misz-Kennan, M. Predeanu, G. Montes, J.r. Rodrigues, S. Siavalas, G., Wagner, N. (2017), Development of a petrographic classification of fly-ash components from coal combustion and co-combustion (An ICCP Classification System, Fly-Ash Working Group - Commission III), International Journal of Coal Geology 183, pp. 188-203

Suárez-Ruiz, I. i Valentim, B. (2015), Atlas of Fly Ash Occurrences Identification and Petrographic Classification of Fly Ash Components Working Group. Commission III - ICCP p. 203.

\begin{abstract}
.
Numerous varieties of solid fuels have been employed for the production of heat in buildings and during cooking by utilizing furnaces and boilers. The most commonly used energy carriers include hard and brown coal, coke, and wood-based solid biofuels in the form of various types of pellets, briquettes, and chips. Notably, furnace and boiler users can combine these fuels in any way by changing their proportions. Generally, users of furnaces and boilers are known to co-burn solid fuels and various types of municipal waste. However, the municipal waste contains a number of organic compounds and toxic metals that can be released into the atmosphere during the combustion process; this poses a threat to the health of the environment and public. Herein, chemical and petrographic tests were performed to study the sources of furnace wastes. This research facilitates the identification of unacceptable substances such as plastics, metal filings, and glass.
\end{abstract}

Keywords: waste combustion, solid biofuels, coal, wood chips, waste 